\title{
Measuring the technophobia among middle-aged and older adults in Latvia: A pilot study
}

\author{
Ilona Zarina, Kristaps Circenis, and Renars Erts \\ Rīga Stradiņš University, Latvia
}

\begin{abstract}
The increasing need for the development of new solutions for older adults in order to support the independent living at home is perspicuous. The rapid development of information and communication technology will provide capable solutions for maintaining of life quality. Computerized technology is devoted to improving our quality of life. By the way, here is a segment of the population who do not have access to the technology in any way or form because technophobia. The aim of the pilot study was to translate measurement instrument of technophobia "Technophobia test" and collect data needed for analysis and adaptation process. The following research tasks were completed: upon examination of the available literature, the most accepted instruments for measuring technophobia are the Computer Anxiety Rating Scale (Form C), the Computer Thoughts Survey (Form C) and the General Attitudes towards Computers Scale (Form C). In Latvia, up to now such research has not been carried out. Participants (62) were middle-aged and older persons, aged from 45 to 87 years. The descriptive statistic parameters of Technophobia test subscales and the reliability statistical parameter Cronbach's alpha were calculated and average level of technophobia was assessed.
\end{abstract}

Key words: older adults, gerontechology, technology use, technophobia, technophobia test.

\section{Introduction}

Aging of the population is taking place in most countries around the world, and older people make up the fastest growing population group.

Mortality prevalence over birth and negative net migration in Latvia have caused also changes in the structure of population's age. It should be noted that since 2011 the share of children and youngsters (0-14 years) in the total population has slightly increased (that may be explained by a modest rise in the birth number), nevertheless the number of people at working age (15-61 years) is continuously reducing, and the share of population at retirement age (62 years and over) is rising. The number of persons at working age has dropped by 120 thousand since 2011, while the number of people over working age has gone up by 8.5 thousand. Population ageing is intensifying. Drop in the population at working age is notably affected by the migration. In 2015, two times more people at working age emigrated from the country (16.8 thousand), as compared to the number of immigrants at this age (7.2 thousand). Since 1993, the share of people at retirement age exceeds the share of children and young people, and it means that in future the number of population at working age will be smaller and the level of demographic burden will increase. At the beginning of 2016, 
per 1000 population at working age there were 377 persons of retirement age and 248 children aged under 15 . At the beginning of 2016 the average age of the population of Latvia was 42.2 years-38.9 years among males and 44.9 years among females [1].

Technology creation, adaptation and its use by older people in health care are becoming increasingly important in our society. Technology includes a variety of technical systems and solutions to help the older adults and/or their caregivers to perform daily activities and maintain autonomy or compensate for the functional disorders. The emergence of gerontechnology has been shown to be a possible solution for the aging-related health, family and social burdens. Gerontechnology combines gerontology and technology, and involves the research and development of techniques, technological products, services and environments based on knowledge of ageing processes. Recently, research has shown that use of a variety of gerontechnology by older adults can help them to lead lives that are healthier, more independent, and more socially engaging on a continual basis. The development of telecommunication can remotely connect elderly patients with health professionals and care givers, and thereby to accomplish the shift from traditional institution-based health caring to home/community-based health care [2].

Computer and Internet use is one of the most common ways of using technology. The Internet is an important source of information on health, in patients who feel discerning and take action to improve their health.

According to the Central Statistical Bureau Latvia, the 2016 survey of information and communication technologies in households $-49 \%$ of the older generation (55-74 years old) respondents use the Internet. However, it should be noted that the number of Internet users among seniors in one year has increased by 2 percentage points compared to 2015 , when it was $47 \%$.

There are various reasons why the people at home do not have Internet access. In 2016 as the main reason is mentioned that the Internet is required (56\%) and the lack of skills in using the Internet (28\%). The share of regular Internet users is directly proportional to the level of educational attainment. Latvian senior citizens (aged 65 years and over) were born before the Second World War, during the war, or a couple of years after the war ended. It was also largely determined by their educational opportunities, which have not always been favourable enough to obtain a high level of education. In the age group of 65 years a different level of education can be seen compared to the distribution for the overall population. In this age group, the majority of the population $(29.7 \%$ ) have primary education, while $27.2 \%$ professional education or Professional secondary education [1].

In Latvia, in 2015 the Internet was mostly used to read online news, newspapers and magazines (87\% of Internet users), as well as to use email (87\%) and online banking $(81 \%)$ [1].

The use of gerontechnology as any innovative approach contains both significant benefits and risks. For instance, little is known about how older adults estimate and rank technologies. What are the circumstances that middle-age and older adults experience? Factors influencing usage of technology have been studied more widely.

However, older adults often lack confidence in their computer skills, according to Marques, Jourdan-Boddaerti and Huet [3]. They concluded that older adults are less confident about their computer knowledge than younger adults, regardless of age equivalence of actual performance. The research results show that this belief may make it difficult to learn new computer technology [3]. Selwyn [4] showed that even among those older adults, who had access to the computer, there was a low level of use and, as the main reason for not using computers was a lack of interest or self-perception as an older adult. They also found that most of the older computer users were males, well educated, and the most recent group of older adults. 
Meanwhile computerized technology spreads in our homes, our cars and our lives are devoted to improving our quality of life by providing more time for leisure. Unfortunately, here is a segment of the population who do not have access to the technology in any way or form because of technophobia, when actual or imaginary interactions with computers and any kind of technology can cause anxiety reactions typical of other phobias or cause a negative internal dialogue that belittle their abilities and undermine their confidence.

This problem is common more often than we might think. Surveys of students and business people have estimated that one-third of all people feel uncomfortable with computer technologies [6-8]. For some, this discomfort is lightweight and can be alleviated by experience. For many others this problem is more severe and often causes severe discomfort and impaired capabilities of use of the computer or any kind of technology, as well as the avoidance of all computers and computer-related technologies as much as possible.

Jay defined computerphobia or technophobia, or technostress as: (a) a resistance to talking about computers or even thinking about computers, (b) fear or anxiety toward computers, and (c) hostile or aggressive thoughts about computers. Jay's work has been widely quoted as a rationale behind over 20 separate measures of computer attitudes, computer anxiety and computer aversion [9].

The majority of literature devoted to technophobia confines the definition of technophobia to that of popular consumer of electronic goods, such as computers and computer-related technologies. Various terms abound to describe technophobia, including "technostress", "cyberphobia", "computer aversion" and "computer anxiety", with the majority of these terms defining technophobia as computer-specific [10].

The irrational fear, anxiety and apprehension towards new modern technologies entering the innovation curve, manifested in the unwillingness of an individual to adopt the technology. Technophobia can further be defined as negative attitudes, thoughts and behaviours that directly or indirectly result from new technology goods, services or ideas.

Rosen, Sears and Weil [11] developed a series of measurement instruments to assess levels of technophobia or computerphobia, which they describe as "anxiety about present or future interactions with computers or computer-related technology; negative global attitudes about computers, their operation or their societal impact; and / or specific negative cognitions or self-critical internal dialogues during actual computer interaction or when contemplating future computer interaction" (pp. 8). These research instruments have been used and validated in more recent studies [12-18] and are used in this study in order to assess levels of technophobia in older adults. Both users and non-users of computers were tested.

\section{Objective and tasks}

The objective of the research was to translate in Latvian and perform adaptation process of the Technophobia test among middle-aged and older adults in Latvia.

The tasks of the research were: forward translation of the instrument; pre-testing and interviewing; final version application; the descriptive statistic parameters of Technophobia test subscales and the reliability statistical parameter Cronbach's alpha calculation; the average technophobia level of participant assessment.

\section{Methods}

Research was carried out using quantitative method. The research instrument adaptation process was performed. The ITC Guidelines for Translating and Adapting Test (second edition, 2016) was used. The survey was carried out in translation and realization of pilot study. 
Translation of the text was used for one-way approach, four translators independent on each other carried out the translation, it was followed by a discussion, and adjustments were made. Four translators independently did translation, and after discussion some adjustments were made. Final version was given to small sample of respondents. We did not receive any critical comments or suggestions. To check the reliability of the test the Cronbach's alpha was calculated for each subscale. Descriptive statistics was used for the evaluation of data.

After the final version harmonization was carried out in this pilot study.

The test was carried out in the translated versions of empirical verification of the pilot study. The test was completed by 62 respondents. The selection criterion was age - from 45 years. Each respondent was introduced with the aim of the study, maintained confidentiality and other ethical principles of voluntary participation.

The questionnaire was divided into 4 parts:

The first part collected demographic data and also "yes" or "no" answer to the question of whether the respondents had a special education related to computer training.

For translating and adapting were selected the other three parts of the Technophobia tests, created and validated by Dr. Rosen and Dr.Weil [12]. These are:

- questions related to computer anxiety - Computer Anxiety Rating Scale Form C (CARS-C)

- questions related to computer thoughts - Computer Thoughts Survey Form C (CTS-C)

- questions related to general attitudes to computer - General Attitudes Towards Computers Scale Form C (GATCS-C).

This consisted of 20 statements, reflecting both positive and negative attitudes towards computers. Respondents were required to indicate their level of agreement with the statements using a five-point Likert scale.

\subsection{Design of the research instrument}

CARS contains 20 Likert scale questions scored from 1 to 5 with 1 indicating a response of "not at all" and 5 reflecting a response of "very much". CARS contains items created to assess technological anxiety that includes anxiety about computer programming, learning computer, use and issues with computers and technology. Higher scores indicate more computer anxiety.

CTS was modelled after the CARS with a similar 20 Likert scale questions that rank from "not at all" to very often". CTS reflects how often the respondent had each thought when working or thinking of technology. 11 items are phrased in the negative direction and 9 items are phrased in the positive direction. Higher CTS scores indicate more positive cognitions and feelings toward computers and technology.

GATS includes 20 statements, each addressed on a 5 point Likert scale from "Strongly agree" to "Strongly disagree". 10 items are phrased in the positive direction and 10 in the negative direction. Higher GATS scores indicate more positive general attitudes toward computers and technology. The minimum possible score is 20 , the maximum is 100 points on each scale.

\subsection{Research tool validation}

The Questionnaire was developed originally by Rosen and Weil, 1992, following 14 studies using research best practices with thousands of university students, elementary and secondary school teachers, business people and secondary school students. This included a study of 3392 students in 38 universities from 23 countries [19]. 
Table 1. Descriptive statistic parameters of Technophobia test $(N=62)$.

\begin{tabular}{|l|c|c|c|}
\hline & $\begin{array}{c}\text { Computer Anxiety } \\
\text { Rating Scale }\end{array}$ & $\begin{array}{c}\text { Computer } \\
\text { Thoughts Survey }\end{array}$ & $\begin{array}{c}\text { General Attitudes } \\
\text { Towards } \\
\text { Computers Scale }\end{array}$ \\
\hline Minimal value & 27.00 & 36.00 & 42.00 \\
\hline Maximal value & 95.00 & 84.00 & 75.00 \\
\hline Range & 68.00 & 48.00 & 33.00 \\
\hline Mean & 46.35 & 64.12 & 62.03 \\
(SD) & $(18.81)$ & $(10.07)$ & $(6.53)$ \\
\hline
\end{tabular}

Table 2. Cronbach's alpha parameters of Technophobia test scales $(N=62)$.

\begin{tabular}{|l|c|}
\hline Scale & Chronbach's alpha \\
\hline Computer Anxiety Rating Scale & 0.95 \\
\hline Computer Thoughts Survey & 0.81 \\
\hline General Attitudes Towards Computers Scale & 0.55 \\
\hline
\end{tabular}

Table 3. An average results from all scales.

\begin{tabular}{|l|l|}
\hline Scale & Average results $(\boldsymbol{n}=\mathbf{6 2})$ \\
\hline Computer Anxiety Rating Scale & 45 (low technophobia level 42-49) \\
\hline Computer Thoughts Survey & 65 (low technophobia level 61-68) \\
\hline Computer Thoughts Survey & 60 (low technophobia level 56-63) \\
\hline
\end{tabular}

These instruments have been used by many other authors (Hogan, 2006; Heinssen et al., 1987; North and Noyes, 2002; McIlroy, et al., 2001) [20] validating Dr. Rosen and Dr. Weil's work. It was therefore eligible to use scales for pilot study in the situation of Latvian condition.

Descriptive statistics was used for the evaluation of data. The computations were carried out with SPSS for Windows, version 20.0, statistical software and Excel Microsoft. The results were quantified.

\section{Results}

The participants in the pilot study consisted of middle-aged and older adults (48 women and 14 men) who were Vidzeme region residents in Latvia. They ranged in age from 57 to 87 and consisted of eight men and 54 women. The average age of respondents was 70.48 years. Their level of computer experience ranged from none to extensive.

Averages for Technophobia test subscales are shown in Table 1. The average mean for Computer Anxiety rating Scale was 46.35 ( $S D=18.81$ ), Computer Thoughts Survey mean was $64.12(\mathrm{SD}=10.07)$, for General Attitudes Towards Computers Scale mean was 62.03 $(\mathrm{SD}=6.53)$.

The reliability statistical parameter Cronbach's alpha was calculated for each subscale and the results are shown in Table 2. The highest Cronbach's alpha coefficient (0.95) was for Computer Anxiety Rating Scale, while for Computer Thoughts Survey it was 0.81 and for General Attitudes Towards Computers Scale 0.55.

The average level of tehnophobia was tested. For all scales higher scores indicate more computer anxiety, less negative cognitions and less negative attitude. Initial results showed a low level of technophobia in all scales. The results are shown in the Table 3. 


\section{Discussion}

The main benefit of the research is performed translation of the Technophobia test in Latvian and adaptation process for middle-aged and older adults in Latvia. The descriptive statistical parameters of each subscale were calculated.

Several researchers have tried to pin down Technophobia to specific age groups. For example, in a study of adoption of interactive teleshopping, Eastlick (1996, cited in Meuter et al., 2003) states that non-adopters were the older generation, similarly Raub (1981, cited in Brosnan 1998) reported that older people where more anxious then younger people with Laguna and Babcock (1997) supporting this notion. However demographic variables have not consistently explained technology usage and adoption (Meuter et al. 2003). In the study of Rosen and Weil (1995) for Technophobia amongst Public School Teachers it transpired that teachers' age was not related to computer use. Similarly in a study of about 3,000 university students among 23 countries, age was not related consistently with technophobia. This is in line with Charness, Schumann and Boritz (1992, cited in Laguna \& Babcock 1997) who found no significant age differences in computer anxiety between younger and older adults [21].

\section{Conclusion}

As a result of present research the descriptive statistical parameters of translated Technophobia test (version C) subscales were obtained. The data analysis was performed including subscales reliability calculations. Initial results showed a low level of technophobia in all scales. This sample consisted only of older adults, which may also have had a bearing on the results as the other studies mainly consisted of students and so, the effect of experience may be different for older and younger adults.

Data analysis shows that Cronbach's alpha numbers in all subscales are quite high, which means good internal reliability of subscales. The confidence data of subscales are close to the original author's test reliability parameters and data shown in other studies.

It would be desirable to carry out another empirical study, selecting respondents by age, sex. This will allow for more complete conclusions.

\section{References}

[1] Informācijas un komunikācijas tehnoloğiju lietošana mājsaimniecībās 2015.gadā, informatīvs ziņojums, Centrālā statistikas pārvalde: http://www.csb.gov.lv/ statistikas-temas/metodologija/datoru-un-interneta-lietosanamajsaimniecibas-37295.html (2016)

[2] K. Chen, A. Hoi-shou, Int. J. Environ. Res. Public Health 10(10), 4645-4666 (2013), Published online 2013 Sep 30. doi: 10.3390/ijerph10104645

[3] J.C. Marquie, L. Jourdan-Boddaert, N. Huet, Behav. Inform. Technol. 21(4), 273-280 (2002)

[4] R.W. Morrell, C.B. Mayhorn, J. Bennet, Hum. Factors 42(2), 175-182 (2000)

[5] N. Selwyn, S. Gorard, J. Furlong, L. Madden, Aging Soc. 23, 561-582 (2003)

[6] R.K. Heinssen, C.R. Glass, L.A. Knight, Comput. Hum. Behav. 3, 49-59 (1987)

[7] L.D. Rosen, D.C. Sears, M.M. Weil, Behav. Res. Methods Instrum. Comput. 19, 167-179 (1987)

[8] S. Weinberg, M. Fuerst, Computer phobia: How to slay the dragon of computer fear (Banbury Books, Wayne, PA, 1984)

[9] T.B. Jay, Educ. Technol. 21, 47-48 (1981) 
[10] R.R. Sinkovics et al., Thunderbird Int. Business Rev. (USA) 44(4), 477-494 (2002) [Online] Available from: Emerald: http://www.emeraldinsight.com.innopac. up.ac.za/Insight/viewContentItem.do; jsessionid=6ACACC4A3859EA799B 82B27ECC5CADFA? contentType=Review\&contentId=1362464 [Accessed: 201703-23]

[11] L.D. Rosen, D.C. Sears, M.M. Weil, Measuring Technophobia. A Manual for the administration and scoring of three instruments: Computer Anxiety Rating Scale (Form C), General Attitudes Toward Computers Scale (Form C) and Computer Thoughts Survey (Form C). (California State University, Dominguez Hills, Computerphobia Reduction Program, 1992)

[12] M. Hogan, Irish J. Manage. 27(1), 57-77 (2006)

[13] L.D. Rosen, P. Maguire, Anxiety Res. 3, 175-191 (1991)

[14] M. Gordon, M. Killey, M. Shevlin, D. McIlroy, K. Tierney, Comput. Hum. Behav. 19(3), 291-298 (2003)

[15] A.A. Anderson, Comput. Hum. Behav. 12(1), 61-77 (1996)

[16] M.J. Brosnan, J. Comput. Assisted Learning 14, 223-234 (1998)

[17] L.M. Anthony, M.C. Clarke, S.J. Anderson, Comput. Hum. Behav. 16, 31-44 (2000)

[18] A.R. Korukonda, Inf. Sci. 170(2-4), 309-328 (2005)

[19] M.M. Weil, L.D. Rosen, Comput. Hum. Behav. 11(1), 95-133 (1995)

[20] L. Uden, Fr. Herrera, J.B. Perez, J.M.C. Rodriguez, 7th International Conference on Knowledge Management in Organizations: Service and Cloud Computing (SpringerVerlag Berlin Heidelberg, 2013), pp. 117-127

[21] C. Aquilina, Exploring the extent of Technophobia: a study conducted in the Maltese Public Service (University of Derby, 2011) 